\title{
ОСОБЛИВОСТІ ЛІКУВАННЯ ГОСТРОГО ХОЛЕЦИСТИТУ В ПАЦІЄНТІВ ПОХИЛОГО ТА СТАРЕЧОГО ВІКУ
}

\section{Особливості лікування гострого холециститу в пацієнтів похилого та старечого віку \\ В. К. Чурпій \\ Центральноукраїнський інститут розвитку людини Відкритого міжнародного університету розвитку людини «Україна», м. Кропивницький}

Резюме. Гострий холецистит - найчастіша ургентна абдомінальна патологія. Убільшостівипадків причиною захворювання слугує жовчнокам'яна хвороба. Приблизно половина пацієнтів із гострим холециститом - похилого та старечого віку. Застосування малоінвазивних технологій дозволяє виконувати адекватний обсяг оперативного втручання при мінімальній травматичності.

Мета дослідження - розглянути наукові підходи до вирішення питання тактики хірургічного втручання при гострому холециститі у хворих похилого і старечого віку.

Матеріали і методи. Опрацьовано бази даних Pubmed, medLine, EmBASE, CINAHL, PsycINFO, пошук включав публікації до 2020 р. Дослідження були використані за умови, що вони відповідали такому критерію: метою їх стало виокремлення тактики хірургічного втручання при гострому холециститі у хворих похилого і старечого віку.

Результати. Отримані результати останніх досліджень дозволяють краще зрозуміти питання тактики хірургічного втручання при гострому холециститі у хворих похилого і старечого віку, а також відкривають шлях для подальших досліджень. Найпоширенішими чинниками, які обмежують активну хірургічну тактику, виступають наявність у геронтологічних пацієнтів одночасно декількох патологій, а також пізня госпіталізація. Застосування консервативної терапії з метою ліквідації запального процесу і стабілізації супутньої патології не завжди є ефективним, призводить до вимушених операцій на фроні ускладнень та декомпенсації системних захворювань. Поява нових діагностичних і малоінвазивних лікувальних технологій дозволила впровадити у геронтологічних пацієнтів активну хірургічну тактику з короткою передопераційною консервативною підготовкою.

Висновки. Виконання традиційної холецистектомії у пацієнтів із гострим холециститом пов'язане з високим операційно-анестезіологічним ризиком і по-
Features of acute cholecystitis treatment in elderly and senile patients

V. K. Churpiy

Central Ukrainian Institute of Human Development of the Open International University of Human Development "Ukraine", Kropyvnytskyi

e-mail: volodymyrchurpii1@gmail.com

Summary. Acute cholecystitis is the most common urgent abdominal pathology. Cholelithiasis is the cause of the disease in most cases. Approximately half of the patients with acute cholecystitis are elderly and senile. The use of minimally invasive technologies allows performing an adequate amount of surgical intervention with minimal trauma of the operation.

The aim of the study - to consider scientific approaches to solving the question of the tactics of surgical intervention in acute cholecystitis in elderly and senile patients.

Materials and Methods. The databases Pubmed, medLine, EmBASE, CINAHL, PsycINFO were used, the search included publications until 2020. The studies met the following criterion: studies aimed at identifying the tactics of surgical intervention in acute cholecystitis in elderly and senile patients.

Results. The results of recent studies allow us to better understand the tactics of surgical intervention in acute cholecystitis in elderly and senile patients, and also open the way for further research. The most common factors limiting active surgical tactics are the presence of several pathologies in gerontological patients at the same time, as well as late hospitalization. The use of conservative therapy in order to eliminate the inflammatory process and stabilize the concomitant pathology is not always effective, it leads to forced operations against the background of complications and decompensation of systemic diseases. The emergence of new diagnostic and minimally invasive treatment technologies has made it possible to introduce active surgical tactics with short preoperative conservative preparation in gerontological patients.

Conclusions. Performing traditional cholecystectomy in patients with acute cholecystitis is associated with a high surgical and anesthetic risk and mortality rates. The use of minimally invasive methods of treatment can reduce the degree of intraoperative and postoperative risk. Taking into account the high level of mortality and frequent complications this direction requires a further study. 
казниками летальності. Застосування малоінвазивних методів лікування дозволяє зменшити ступінь інтраопераційного і післяопераційного ризику. Зважаючи на високий рівень летальності, часті ускладнення, даний напрямок потребує подальшого вивчення.

Ключові слова: жовчнокам'яна хвороба; гострий холецистит; пацієнти похилого та старечого віку; традиційна холецистектомія; малоінвазивні технології оперативного втручання.

\section{ВСТУП}

Жовчнокам'яна хвороба - багатофракторне і багатостадійне захворювання гепатобіліарної системи, з генетичною схильністю, зумовлене порушенням обміну холестерину і/або білірубіну, що характеризується утворенням жовчних каменів у печінкових жовчних протоках (внутрішньопечінковий холелітіаз), в загальній жовчній протоці (холедохолітіаз) або в жовчному міхурі (холецистолітіаз) $[1,2]$. Калькульозний холецистит - це запальний процес у порожнині жовчного міхура, що виникає через камені, які відклалися в ньому, причому ці камені сорормовані саме через холестерин, барвник, наявний в жовчі й домішки кальцію.

Наразі частотність жовчнокам'яної хвороби становить 5-25 \% у дорослого населення і частіше носить безсимптомний характер [3]

За частотою зустрічальності гострий холецистит (24,4 \%) лише на 2 \% відстає від гострого апендициту і займає друге місце серед гострих хірургічних захворювань органів черевної порожнини. Протягом життя у 20 \% пацієнтів із жовчнокам'яною хворобою розвивається гострий холецистит, який є другою за частотою (після гострого апендициту) причиною ускладненої інтраабдомінальної інфрекції [4].

Гострий холецистит, таким чином, - найбільш часта ургентна абдомінальна патологія. У більшості випадків причиною захворювання слугує жовчнокам'яна хвороба. Пацієнти з гострим холециститом становлять близько 15 \% госпіталізованих хірургічного профрілю, приблизно 50 \% 3 них - люди похилого та старечого віку.

Кількість діагностованих жовчних каменів збільшується з віком, так, у пацієнтів у віці старше 60 конкременти виявляються в 20-30 \% випадків [2] і збільшується до 80 \% в осіб у віці старше 90 років [6].

У 10-18 \% пацієнтів із відсутністю симптомів протягом життя розвивається жовчна коліка, а 7 \% піддаються оперативному втручанню [7]. У 1-4 \% госпіталізованих хворих розвиваються ускладнення, такі, як гострий холецистит (OX), біліарний панкреатит і холедохолітіаз.

Тож проблема лікування гострого холециститу часто $є$ геріатричною проблемою. Наразі спостерігається тенденція збільшення в хірургічних відді-
Key words: cholelithiasis; acute cholecystitis; elderly and senile patients; traditional cholecystectomy; minimally invasive surgical intervention technologies.

леннях питомої ваги пацієнтів похилого та старечого віку, які є основною групою ризику післяопераційних ускладнень та летальності. Сьогодні особи похилого та старечого віку представляють 10-25 \% усіх хворих на гострий калькульозний холецистит. Високий операційно-анестезіологічний ризик, супутні захворювання та низький опір операційній травмі $є$ причиною високої частоти післяопераційних ускладнень і летальних наслідків у цієї категорії пацієнтів. Післяопераційна летальність в геронтологічних пацієнтів в 10-20 разів вища, ніж у молодих, і складає 820 \% [8]. 3 віком збільшується кількість захворювань, ступінь їх декомпенсації, загальна дезадаптація і дезорганізація фрункціональних систем організму. Хоча початок таких захворювань припадає переважно на середній вік, результат їх сумарного накопичення починає проявлятися в похилому віці [1].

Незважаючи на часту зустрічальність гострого холециститу в повсякденній практиці, інтерес до проблеми його лікування не зменшується. При такому великому і всебічному вивченні проблеми, наявності міжнародних та національних рекомендацій, $є$ і невирішені питання, серед яких, зокрема, і проблема лікування гострого калькульозного холециститу в людей похилого і старечого віку.

Метою дослідження було розглянути наукові підходи до вирішення питання тактики хірургічного втручання при гострому холециститі у хворих похилого і старечого віку.

\section{МАТЕРІАЛИ I МЕТОДИ}

Опрацьовано бази даних Pubmed, medLine, EmBASE, CINAHL, PsycINFO, пошук включав публікації до 2020 р. Дослідження були використані за умови, що вони відповідали такому критерію: метою їх стало виокремлення тактики хірургічного втручання при гострому холециститі у хворих похилого і старечого віку.

\section{РЕЗУЛЬТАТИ Й ОБГОВОРЕННЯ}

Згідно з дослідженнями науковців, вік хворих має важливе значення як у визначенні тактики лікування гострого калькульозного холециститу, так і в оцінці його результатів. Найпоширенішими чинниками, що обмежують активну хірургічну тактику, 
виступають наявність у геронтологічних пацієнтів патологій серцево-судинної, дихальної, ендокринної, ниркової систем, які виявляються у більшості випадків, при чому частими є одночасні декілька супутніх захворювань у пацієнтів похилого віку, для яких також властива пізня госпіталізація [9, 10].

В останні роки досягнуто зниження післяопераційної летальності при гострому холециститі, яка в даний час становить 0,28-2,9 \% [6], при гангренозному холециститі вона вища - до 17,8 \% [11]. Післяопераційна летальність особливо висока в старших вікових групах, що зумовлено значною мірою наявністю і вираженням супутніх захворювань.

Крім віку і супутніх захворювань, до фракторів, що визначають ризик операції і летальність, відносять також термін від появи перших симптомів гострого холециститу до госпіталізації пацієнта.

У наукових публікаціях наводяться різні терміни щодо того, коли пацієнти з гострим холециститом звертаються до лікарні. Переважно автори вказують, що в термін до доби від початку захворювання звертається тільки п'ята частина хворих [12]. У дослідженнях вказується лише час, що минув від госпіталізації до операції [13]. Хоча цей показник простіше хронометрирувати, проте, з іншого боку, відсутність даних про терміни захворювання не дозволяє однозначно характеризувати i, отже, порівнювати групи хворих.

Спостерігається тенденція: чим старший контингент хворих, тим пізніше вони звертаються за медичною допомогою, у них частіше зустрічаються деструктивні форми гострого холециститу, вираження супутніх захворювань лімітує хірургів у виборі методу лікування, вища частота післяопераційних ускладнень. Таким чином, у хворих похилого та старечого віку частіше діагностуються деструктивні та ускладнені форми гострого калькульозного холециститу.

Наразі практично відсутні загальноприйняті критерії діагностики гострого холециститу, визначення його тяжкості й стандартизованих підходів до тактики лікування. Зважаючи на це, група експертів у 2006 р. на міжнародній погоджувальній зустрічі 3 лікування гострого холециститу та гострого холангіту в м. Токіо, ґрунтуючись переважно на принципах доказової медицини, визначила діагностичні критерії гострого холециститу та запропонувала диореренціювати хворих на гострий холецистит на 3 групи за тяжкістю перебігу. Група експертів розробила лікувальний алгоритм для кожного ступеня тяжкості захворювання [14].

Згідно з розробленими рекомендаціями, холецистит I ст. - це гострий холецистит у пацієнта із малими запальними змінами в жовчному міхурі, що дозволяє вважати холецистектомію безпечним втручанням.

Гострий холецистит середнього ступеня тяжкості (II ст.) також не супроводжується органною дисорунццією, але виражені запальні зміни жовчного міхура роблять виконання холецистектомії більш небезпечним. Критерії визначення середнього ступеня тяжкості гострого холециститу наступні:

- термін від початку захворювання складає понад 72 год;

- лейкоцитоз понад 18х10\%;

- інфрільтрат у правому верхньому квадранті живота, який виявляється під час пальпації;

- виражені запальні зміни (жовчний перитоніт, абсцес печінки, гангренозний холецистит, емфрізематозний холецистит) [15].

Ці критерії, у тому числі й термін від початку захворювання, були визначені на підставі наявних досліджень із різним рівнем доказовості, так як в терміни понад 96 год і при виражених запальних змінах жовчного міхура зростають ризики ускладнень лапароскопічної холецистектомії і частоти конверсій (рівень доказовості 2 2b-4) [16].

Тяжкий перебіг гострого холециститу (IIIст.) супроводжується дисорункцією одного з наступних органів або систем:

- серцево-судинна недостатність (гіпотензія, що вимагає корекції дофраміном у дозі $\geq 5$ мг/кг на хвилину або будь-якою дозою добутаміну);

- неврологічні порушення (зниження рівня свідомості);

- дихальна недостатність (співвідношення $\mathrm{PaO}_{2} /$ $\mathrm{FiO}_{2}<300$ );

- ниркова недостатність (олігурія, креатинін $>2$ мг/дл (177 мкмоль/л));

- печінкова дисфрункція (МНО>1,5);

- тромбоцитопенія (менше 100×10\%/л) [17].

В останні декілька років проблема лікування деструктивного холециститу в пацієнтів похилого та старечого віку неодноразово обговорюється в наукових дослідженнях.

Це пояснюється специфрікою клінічного перебігу гострого калькульозного холециститу в пацієнтів у цей віковий період. У працях відзначається з одного боку відсутність чіткої симптоматики, а з іншого боку - проблематичність обстеження пацієнтів, які потратили до лікарні в пізні терміни [17]. Проте всі дослідження схиляються до думки про складність клінічної та інструментальної діагностики гострого калькульозного холециститу в пацієнтів похилого та старечого віку через невідповідність між тривалістю запального процесу, вираження клінічної симптоматики та патоморфологічні зміни в стінці жовчного міхура [18].

У патогенезі розвитку гострого холециститу в пацієнтів похилого та старечого віку важливе значення відіграють системні й локальні гемодинамічні розлади, порушення вуглеводного обміну, зміни імунної відповіді, пов'язані з віком хворих, тривалість захворювання та інші супутні патології 
[15]. Найчастіше супутніми паталогіями герентологічних хворих $€$ генералізований атеросклероз, обструктивні захворювання легень, паталогії сечостатевої системи та цукровий діабет 2 типу. Ситуація ускладнюється ще й через те, що порушення у таких пацієнтів найчастіше спостерігаються одночасно в декількох системах органів. Як правило, у цих пацієнтів вже спостерігаються ускладнення гострого калькульозного холециститу: місцевий перитоніт, паравезикальний інорільтрат, емпієма жовчного міхура, біліарний панкреатит та ін.

У зв'язку $з$ цим має бути здійснений зважений вибір хірургічної тактики й анестезіологічного забезпечення. Практично усі герентологічні хворі на гострий холецистит вимагають корегуючої передопераційної терапії, яка триває до декількох днів.

Як відомо, основним методом лікування хворих із гострим холециститом $€$ холецистектомія, яка до цього часу залишається «золотим стандартом» в лікуванні хворих з даною патологією [19].

Необхідно зазначити, що першу холецистектомію виконав німецький хірург C. Langenbuch y 1882 р. В останні десятиліття, завдяки інтенсивному розвитку інноваційних технологій, на зміну традиційній холецистектомії прийшли малоінвазивні методи - апароскопічна холецистектомія і холецистектомія 3 міні-доступом або «міні-холецистектомія». Першу ЛХЕ в 1985 р. вперше виконав у Франції Erich Muche.

Виконання першої холецистектомії із міні-доступом належить М. І. Прудкову [20].

Незважаючи на постійне удосконалення хірургічної тактики, використання малоінвазивних технологій, результати таких операцій не можуть задовольняти хірургів, так як післяопераційні ускладнення коливаються в межах від 2,0 до 5,8 \%, а післяопераційна летальність становить 2,011,0 \%, яка стає ще більш значною у хворих похилого та старечого віку.

Багаторічна міжнародна хірургічна практика і накопичений досвід дозволили П. С. Ветшеву і співавт. [20] виділити і сорормулювати ключові положення проблеми хірургічного лікування хворих із гострим холециститом:

- гострий холецистит - неодмінне показання до хірургічного лікування;

- традиційна холецистектомія є найбільш відпрацьованою в плані інтраопераційних ускладнень операцією. Вона залишається стандартом для порівняння еорективності нових методів хірургічного лікування. Своєчасний перехід від операцій малих доступів до традиційної холецистектомії не можна вважати ускладненням (або невдачею), це розумне рішення зрілого хірурга;

- операції малих доступів (ЛХЕ і MXE) є операціями вибору для більшості хворих на гострий холецистит. Результати цих операцій більшою мірою залежать не тільки від досвіду і мануальних навичок хірурга, але і від технічного оснащення лікувальної установи, справності складного обладнання. Відсутність належного технічного оснащення робить операції малих доступів нездійсненними або надзвичайно небезпечними для хворого;

- для підвищення безпеки операцій малих доступів необхідні подальші дослідження і технологічні розробки, введення в клінічну практику суворих стандартів та критеріїв оцінки ефективності лікування та якості підготовки хірурга;

- особливу проблему становить лікування захворювань позапечінкових жовчних проток (особливо холангіолітіазу та його найбільш частого варіанту - холедохолітіазу), поки що є основною причиною виконання операцій із традиційного доступу або конверсії [21]. Необхідні подальша розробка й удосконалення методів вирішення протокової патології малоінвазивними способами. Тут еорективнішим є двоетапний підхід до лікування, який має на увазі ендоскопічну санацію жовчних шляхів після ендоскопічної папілосфінктеротомії (ендоскопічна ретроградна літотрипсія, механічна, лазерна, електрогідравлічна та літоекстракція) 3 подальшою холецистектомією.

Холецистолітолапаксія передбачає (після накладення мікрохолецистостоми і купірування запального процесу в жовчному міхурі) поетапне бужування пункційного каналу і дренаж великого діаметра (8-10 мм) на всю довжину жовчного міхура. Протягом 5-6 діб на дренажі фрормується жорсткий канал, через який виконують контактну пневматичну або механічну літотрипсію і літоекстракцію [6]. Кожен етап втручання закінчується контрольною фрістулографрією й УЗД. Необхідно зазначити, що метод холецистолітолапаксії не вимагає загального знеболювання. Втручання проводиться під місцевою інфільтраційною анестезією.

Перехід від традиційної холецистектомії до лапароскопічної холецистектомії був названий «найбільш швидким» з усіх змін у сучасній хірургії [6]. Цьому сприяли безсумнівні переваги ЛХЕ перед TXE - мала травматичність, незначний больовий синдром, косметичність, швидке відновлення працездатності. Крім того, широкому поширенню методики сприяли виробники медичного обладнання, що почали випуск хірургічних інструментів, і засоби масової інформації, що створювали повсюдну рекламу.

У міру накопичення досвіду застосування ЛХЕ були визначені протипоказання до виконання цієї операції, які умовно ділили на загальні (виражені серцево-легеневі зміни, некореговані порушення згортання крові, перитоніт) і місцеві виражені рубцево-інфільтративні зміни в ділянці шийки жовчного міхура й печінково-дванадцятипалої зв'язки, механічна жовтяниця, гострий панкреатит, злоякісне 
ураження жовчного міхура, перенесені операції на верхньому поверсі черевної порожнини [11]. У процесі вдосконалення обладнання, лапароскопічного інструментарію і самої методики на тлі накопичення хірургічного досвіду й розширення наукових досліджень багато протипоказань з розряду абсолютних переходили у відносні або, більш того, взагалі переставали вважатися такими.

Залишається дискутабельним питання хірургічної тактики при гострому холециститі у пацієнтів понад 60 років. Застосування консервативної терапії із метою ліквідації запального процесу і стабілізації супутньої патології не завжди є ефективним, призводить до вимушених операцій на ороні ускладнень та декомпенсації системних захворювань. Поява нових діагностичних і малоінвазивних лікувальних технологій дозволила впровадити у геронтологічних пацієнтів активну хірургічну тактику з короткою передопераційною консервативною підготовкою. Це дозволяє виконати холецистектомію в умовах відсутності типових ускладнень (паравезикального інфільтрату, емпієми жовчного міхура, холангіту та ін.). Поряд із дискутабельними питаннями хірургічної тактики залишаються невизначеними оптимальний об'єм і вид операційного втручання, що відіграє важливу роль у зниженні післяопераційних ускладнень і летальності. В літературі існують неоднозначні твердження щодо ефективності двоетапного хірургічного лікування цих пацієнтів, лапароскопічної холецистектомії із застосування пневмоперитонеуму, холецистектомії з міні-доступом та лапаротомної холецистектомії. Виходячи 3 викладеного, в даний час не існує єдиного погляду на особливості клінічної симптоматики, методології інструментального обстеження та хірургічну тактику при гострому калькульозному холециститі у пацієнтів старших 60 років, що вимагає напрацювання

\section{СПИСОК ЛІТЕРАТУРИ}

1. Carey L. C. Cholecystectomya new standard / L. C. Carey // Ann. Surg. - 2019. - Vol. 309 (6). - P. 617.

2. Incidence of gallstone disease in Italy: results from a multicenter, population-based Italian study (the MICOL project) (the MICOL project) / D. Festi, A. Dormi, S. Capodicasa [et al.] // World J. Gastroenterol. - 2008. Vol. 14 (34). - P. 5282-5289. DOI: 10.3748/wjg.14.5282.

3. The safe use of surgical energy devices by surgeons may be overestimated / A. Ha, C. Richards, E. Criman [et al.] // Surg. Endosc. - 2018. - Vol. 32 (9). - P. 3861-3867.

4. The management of intra-abdominal infections from a global perspective: 2017 WSES guidelines for management of intra-abdominal infections / M. Sartelli, A. ChichomMefire, F. M. Labricciosa [et al.] // World J. Emerg. Surg. - 2017. - Vol. 12. - P. 29. програмного підходу до лікування цієї категорії хворих з урахуванням особливостей патологічного процесу в даному віковому періоді.

До числа невирішених питань необхідно віднести відсутність вітчизняних баз даних і багатоцентрових досліджень, які б дозволили оцінити контингенти геронтологічних хворих на гострий холецистит. Для порівняння результатів хірургічного лікування необхідне удосконалення шкал оцінки ризиків і тяжкості ускладнень операцій та багатокомпонентних схем лікування. Вказані питання окреслюють перспективу наших досліджень.

\section{ВИСНОВКИ}

Наведені дані свідчать про те, що хірургічне лікування хворих на гострий холецистит похилого та старечого віку - проблема, що зберігає свою актуальність.

Застосування малоінвазивних технологій дозволяє виконувати адекватний обсяг оперативного втручання при мінімальній травматичності операції. Але варто сказати, що вибір методу лікування багато в чому визначається досвідом хірурга. Особливо гостро стоїть питання удосконалення лікувальної тактики у пацієнтів похилого та старечого віку.

Наявність поліморбідного фрону і поліфункціональної недостатності змушує диореренційовано підходити до вибору методу лікування гострого калькульозного деструктивного холециститу геронтологічних хворих.

Виконання традиційної холецистектомії у пацієнтів із гострим деструктивним калькульозним холециститом пов'язане з високим операційно-анестезіологічним ризиком і показниками летальності. Застосування малоінвазивних методів лікування дозволяє зменшити ступінь інтраопераційного і післяопераційного ризику.

5. Surgeons have knowledge gaps in the safe use of energy devices: a multicenter cross-sectional study / Y. Watanabe, Y. Kurashima, A. Madani [et al.] // Surg. Endosc. - 2016. - Vol. 30 (2). - P. 588-592.

6. Acute cholecystitis - optimal timing for early cholecystectomy: a french nationwide study / M. Polo, A. Duclos, S. Polazzi [et al.] // J. Gastrointest. Surg. - 2016. - Vol. 19 (11). - P. 2003-2010.

7. Development of symptoms in individuals with gallstones / I. Halldestam, E. L. Enell, E. Kullman, K. Borch // Br. J. Surg. - 2004. - Vol. 91 (6). - P. 734-738.

8. Годлевський А. І. Роль інтраопераційної ультразвукової діагностики у виборі методу оперативної корекції при обструктивній жовтяниці непухлинного ґенезу / А. І. Годлевський, С. І. Саволюк, О. А. Ярмак // Хірургія України. - 2011. - № 1. - С. 45-49.
Вісник медичних і біологічних досліджень Bulletin of Medical and Biological Research
$3(9), 2021$ 
9. Лупальцов В. И. Неотложная хирургия органов брюшной полости и забрюшинного пространства / В. И. Лупальцов, В. Н. Лесовой. - Харьков : Контраст, 2014. -312 c.

10. Tokyo Guidelines 2018: surgical management of acute cholecystitis: safe steps in laparoscopic cholecystectomy for acute cholecystitis (with videos) / G. Wakabayashi, Y. Iwashita, T. Hibi [et al.] // J. Hepatobiliary Pancreat. Sci. - 2018. - Vol. 25 (1). - P. 73-86.

11. Outcomes of early versus delayed laparoscopic cholecystectomy for acute cholecystitis performed at a single institution / A. Kohga, K. Suzuki, T. Okumura [et al.] // Asian. J. Endosc. Surg. - 2018. - Vol. 13 (8). - P. 551-558.

12. Мунтян С. Патогенетичні механізми виникнення та розвитку жовчнокам'яної хвороби / С. Мунтян // Шпитальна хірургія. - 2003. - № 1. - С. 81-84.

13. Saber A. Operative outcome and patient satisfaction in early and delayed laparoscopic cholecystectomy / A. Saber, E. N. Hokkam // Minim. Invasive Surg. - 2014. Vol. 2014. - P. 162-643. DOI: 10.1155/2014/162643.

14. Techniques of biliary drainage for acute cholecystitis: Tokyo Guidelines / T. Tsuyuguchi, T. Takada, Y. Kawarada [et al.] // J. Hepatobiliary Pancreat. Surg. - 2007. - Vol. 14 (1). - P. 46-51.

15. A selective antibiotic prophylaxis policy for laparoscopic cholecystectomy / F. Yanni, P. Mekhail,

\section{REFERENCES}

1. Carey LC. Cholecystectomya new standard. Ann Surg. 2019;309(6): 619. DOI: 10.1097/00000658-19921200000001.

2. Festi D, Dormi A, Capodicasa S, Staniscia T, Attili AF, Loria P, Colecchia A. Incidence of gallstone disease in Italy: results from a multicenter, population-based Italian study (the MICOL project). World J Gastroenterol. 2008;14(34): 5282-9. DOI: $10.3748 /$ wjg.14.5282

3. Ha A, Richards C, Criman E, Piaggione J, Yheulon C, Lim R. The safe use of surgical energy devices by surgeons may be overestimated. Surg. Endosc. 2018;32(9): 3861-7. DOI: $10.1007 / \mathrm{s} 00464-018-6116-1$.

4. Sartelli M, Chichom-Mefire A, Labricciosa FM, Hardcastle T, Abu-Zidan FM, Adesunkanmi AK, Catena F. The management of intra-abdominal infections from a global perspective: 2017 WSES guidelines for management of intra-abdominal infections. World J Emerg Surg. 2017;12: 29. DOI: 10.1186/s13017-017-0141-6.

5. Watanabe Y, Kurashima Y, Madani A, Feldman LS, Ishida M, Oshita A, Hirano S. Surgeons have knowledge gaps in the safe use of energy devices: a multicenter cross-sectional study. Surg Endosc. 2016;30(2): 588-92. DOI: $10.1007 / \mathrm{s} 00464-015-4243-5$.

6. Polo M, Duclos A, Polazzi S, Payet C, Lifante JC, Cotte E, Passot G. Acute cholecystitis - optimal timing for early cholecystectomy: a french nationwide study.. Gastrointest. Surg. 2016;19(11): 2003-10. DOI: 10.1007/ s11605-015-2909-x.

7. Halldestam I, Enell EL, Kullman E, \& Borch K. Development of symptoms in individuals with gallstones. Br J Surg. 2004;91(6): 734-8. DOI: https://doi.org/10.1002/ bjs. 4547 .

8. Hodlevskyi AI, Savoliuk SI, Yarmak OA. [Surgical
G. Morris-Stiff // Ann. R. Coll. Surg. Engl. - 2013. - Vol. 95 (5). - P. 345-348.

16. Preoperative predictors of conversion as indicators of local inflammation in acute cholecystitis: strategies for future studies to develop quantitative predictors / R. Z. Panni, S. M. Strasberg // J. Hepatobiliary. Pancreat. Sci. - 2018. - Vol. 25 (1). - P. 101-108.

17. Overview of current targeted therapy in gallbladder cancer / X. Song, Y. Hu, Y. L [et al.] // Signal. Transduct. Target. Ther. - 2020. - Vol. 5 (1). - P. 230.

18. Immunohistochemical expression of vascular endothelial growth factor A in advanced gallbladder carcinoma / P. Letelier, P. Garcia, P. Leal [et al.] // Appl. Immunohistochem. Mol. Morphol. - 2014. - Vol. 22 (7). - P. 530-536.

19. The safety and prognostic factors for mortality in extremely elderly patients undergoing an emergency operation / S. Y. Park, J. S. Chung, S. H. Kim [et al.] // Surg. Today. - 2015. - Vol. 46 (2). - P. 241-247.

20. Ветшев П. С. Хирургическое лечение холелитиаза: незыблемые принципы, щадящие технологии / П. С. Ветшев, А. М. Шулутко, М. И. Прудков // Хирургия. - 2016. - № 8. - C. 12-19.

21. Mini-laparoscopic cholecystectomy with the MiniLap percutaneous surgical system: a series of 32 patients / K. Sapalidis, C. Kosmidis, N. Michalopoulos [et al.] // Int. J. General Med. - 2018. - Vol. 2018. - P. 369-371.

treatment of cholelithiasis: unshakable principles, gentle technologies]. Khirurhiia Ukrainy. 2011;1: 45-9. Ukrainian.

9. Lupaltsov VI, Lesovoy VN Emergency surgery of the abdominal and retroperitoneal organs. [Неотложная хирургия органов брюшной полости и забрюшинного пространства] Kharkiv: Kontrast; 2014. Russian .

10. Wakabayashi G., Iwashita Y, Hibi T, Takada T, Strasberg SM, Asbun HJ, Yamamoto M. Tokyo Guidelines 2018: surgical management of acute cholecystitis: safe steps in laparoscopic cholecystectomy for acute cholecystitis (with videos). J Hepatobiliary Pancreat Sci. 2018;25(1): 7386. DOI: 10.1002/jhbp.517.

11. Kohga A, Suzuki K, Okumura T, Yamashita K, Isogaki J, Kawabe A, Kimura T. Outcomes of early versus delayed laparoscopic cholecystectomy for acute cholecystitis performed at a single institution. Asian J Endosc Surg. 2018;13(8): 551-8. DOI: 10.1111/ases.12487.

12. Muntian S [Pathogenetic mechanisms of origin and development of gallstone disease]. Shpytalna khirurhiia. 2003;1: 81-4. Ukrainian.

13. Saber A, Hokkam EN. Operative outcome and patient satisfaction in early and delayed laparoscopic cholecystectomy. Minim Invasive Surg. 2014;162: 643. DOI: $10.1155 / 2014 / 162643$.

14. Tsuyuguchi T., Takada T, Kawarada Y, Nimura Y, Wada K, Nagino M, Dervenis C. Techniques of biliary drainage for acute cholecystitis: Tokyo Guidelines. J Hepatobiliary Pancreat Surg. 2007;14(1): 46-51. DOI: $10.1007 / \mathrm{s} 00534-006-1155-8$.

15. Yanni F, Mekhail P, Morris-Stiff G. A selective antibiotic prophylaxis policy for laparoscopic cholecystectomy. Ann R Coll Surg Engl. 2013;95(5): 345-8. DOI: 10.1308/00358841 3X13629960045959. 
16. Panni RZ, Strasberg SM. Preoperative predictors of conversion as indicators of local inflammation in acute cholecystitis: strategies for future studies to develop quantitative predictors. J Hepatobiliary Pancreat Sci. 2018;25(1): 101-8. DOI: 10.1002/jhbp.493.

17. Song X, HuY, Li Y, Shao R, Liu F, Liu Y. Overview of current targeted therapy in gallbladder cancer. Signal Transduct Target Ther. 2020;5(1): 230. DOI: 10.1038/ s41392-020-00324-2.

18. Letelier P, Garcia P, Leal P, lli C, Buchegger K, Riquelme I, Roa JC. Immunohistochemical expression of vascular endothelial growth factor A in advanced gallbladder carcinoma. Appl. Immunohistochem Mol Morphol. 2014;22(7): 530-6. DOI: 10.1097/PAI.0b013e3182a318a9.
19. Park SY, Chung JS, Kim SH, Kim YW, Ryu H, Kim DH. The safety and prognostic factors for mortality in extremely elderly patients undergoing an emergency operation. Surg Today. 2015;46(2): 241-7. DOI: 10.1007/ s00595-015-1147-x.

20. Vetshev PS, Shulutko AM, Prudkov MI. [Surgical treatment of cholelithiasis: unshakable principles, sparing technologies]. Khirurgiia. 2016;8: 12-9. Russian.

21. Sapalidis K, Kosmidis C, Michalopoulos N, Laskou S, Pavlidis E, Mantalovas S, Kesisoglou I. Mini-laparoscopic cholecystectomy with the MiniLap percutaneous surgical system: a series of 32 patients. Int J General Med. 2018; 369-71. DOI: 10.2147/IJGM.S172655. 